\title{
Game-based Learning Increase Japanese Language Learning through Video Game
}

\author{
Yogi Udjaja, Puti Andam Suri, Ricky Satria Gunawan, Felix Hartanto \\ Computer Science Department, School of Computer Science \\ Bina Nusantara University, Jakarta \\ Indonesia 11480
}

\begin{abstract}
This research was purposed to test the effectiveness of learning the Japanese language through a video game. the video game is built for Personal Computer (PC) users to provide Japanese Language education through video games for teens and adults. The research methods used include literature studies of various books, journals, websites, and theories that can support the writing as well as defining the questions for questionnaires to collect useful data. The development of game application methodology used is Game-Based Learning with Enhanced Learning Experience and Knowledge Transfer (ELEKTRA) methodology, which consists of in-depth analysis of the target audience and learning materials. The effectiveness of video games are evaluated using pre-test and post-test methods. From this researches can be seen that video games are effective to increase the users' knowledge of the Japanese language. also, a video game has the capability to increase the user's interest in learning Japanese because of the visual form of the learning process that leads the user to stay engaged with the learning process.
\end{abstract}

Keywords-Video games; ELEKTRA; games-based learning; Japanese; JLPT N5

\section{INTRODUCTION}

From the previous research [1], [2], in 2018, Japan was the second most popular country for continuing education in the world after the UK. Even now, Japan is still in second place [1]. With so many students wanting to continue their education in Japan. In fact, that most Japanese people don't want to use a language other than the Japanese language. Hence, knowledge of the Japanese language is very important. From 100 students studying in Japan, 81\% say that Japanese is difficult to understand [2].

To test fluency in Japanese, we need to take the Japanese Language Proficiency Test (JLPT). According to Haristiani \& Firmansyah, JLPT is a well-known form of Japanese language proficiency test, or in Japanese, it is called Noryoku Shiken [3]. Noryoku Shiken has a Scale from level N5, which is the most basic level, to N1, which is the highest level. From all the tests carried out, Kanji is the most difficult test because Kanji should be integrated into the sentences in the exam, so mastering Kanji is mandatory.

Based on the sample vacancies from Tomodachi-Indo, the JLPT certificate is used as a condition for employment, and vacancies are also available in Indonesia. By understanding Japanese in depth, someone who has a certificate of Japanese language proficiency at the N1 level can get a salary of around
20 million. while for JLPT N2 certificate holders can get a salary of around 10 million, and even N3 and N4 can get vacancies if they can speak Japanese fluently [4].

In Indonesia, the biggest problems in Japanese language education according to Mayantara in 2012 were "Inadequate facilities/equipment" (57.1\%), "Lack of information on teaching methods" (51.9\%), "Lack of teaching materials" (44.4\%), and "Lack of information about Japanese culture and society (39.1\%). This causes the problem of lack of intention to learn $(33.1 \%)$ [5].

Therefore, the creation of a new and fun learning model should be made to increase knowledge of the Japanese language. Usually, the learning model used to learn Japanese is in the form of a textbook. However, often the language conveyed is difficult to understand and tends to be monotonous. But by using multimedia elements, students will be "tricked" by the effects provided such as graphics, animations and unconsciously also learn Japanese.

Currently, there are many approaches to learning through video games. based on research conducted by A. Alamri [6] Learning through video games has advantages including:

1) Increase motivation in learning.

2) Learning through video games is a safe learning model because students do not need to do outdoor activities but still have the same opportunity to apply their knowledge without wasting time and money.

3) Learning through video games is a technology that can be accessed anywhere and is friendly to students with disabilities.

For these reasons, a special video game for learning Japanese was made using the ELEKTRA methodology [7], ELEKTRA is a special method for game-based learning that contributes to the need for a multimedia-based Japanese learning methodology. This video game is made with standards and target abilities ranging from Hiragana, Katakana, to basic Kanji which are likely to appear in JLPT N5, for students who want to continue their education in Japan or just learn Japanese.

In the end, the study will measure the effectiveness of learning Japanese using video games with pre-test and posttest methods to be able to see an increase in someone's knowledge in learning Japanese. 


\section{RELATED RESEARCH}

\section{A. Japanese Language}

The Japanese language is the national language used in Japan. There are three writing systems in the Japanese writing system, namely: Kana, Kanji and Romaji [8]. Kana is one of the Japanese syllabaries which is a phonetic symbol of Chinese characters and in the early ninth century was used by Japanese people to read Chinese characters [9], [10] and is divided into two models, namely, hiragana and katakana. Here hiragana is usually used for grammar instructions while katakana is usually used for words in a foreign language, Fig. 1 .

Meanwhile, kanji are Japanese characters that are ideographic symbols derived from Chinese characters [11], [12] which indicate traditional nouns, adjectives, and verbs. Another Japanese writing system is Romaji. Romaji writing is currently extending not only for stylistic purposes but also to help people who do not speak Japanese to be able to imitate Japanese sounds.

Being able to memorize hiragana, katakana, and kanji characters is a must to be able to understand the Japanese Language because Japanese letters have a different model than the general alphabet [13]. So many researchers are trying to compare various ways so that someone can learn Japanese better and faster [1].

\section{B. Typing Game}

Since the presence of pong as a computerized table tennis game in 1972, the game industry has continued to develop into a very large entertainment business. Currently, video games continue to grow and are divided into many categories such as puzzles, strategy, simulations, RPGs, sports, etc. [14]. This is supported by a shift in the benefits of games which are not only entertaining but are also widely used as learning media [6].

In language learning, people often feel stressed, and it is very difficult to learn, especially when they have to practice the language in the real world. By utilizing this game it can reduce the pressure for someone while studying [14]. In addition, games can form a learner-centered environment [15]. With the right design and the right implementation process, games can increase motivation in learning, especially language learning which will form closer engagement if you play more often and engage in communication.

\begin{tabular}{|c|c|c|c|c|c|c|c|c|c|}
\hline \multicolumn{10}{|c|}{ Kana Development Chart } \\
\hline \multicolumn{4}{|c|}{ Hiragana } & \multirow{2}{*}{$\begin{array}{l}\text { 平仮名 } \\
\text { お推於 }\end{array}$} & \multicolumn{4}{|c|}{ Katakana } & 牌仮名 \\
\hline あ安与 & いけ以 & 宇 & え衣衣 & & ア阿 & 亿伊 & ウ 宇 & 工 江 & 才於 \\
\hline かか加 & き娄機 & く々久 & け计計 & ここ己 & 力 加 & キ 機 & ク 久 & ケ介 & ユ己 \\
\hline ささ左 & しえ之 & す寸寸 & せ世世 & そそ曾 & サ 散 & シ 之 & ス 須 & 七世 & ソ 曾 \\
\hline た太太 & ち方知 & つ,の川 & てそ天 & と亡止 & 夕 多 & 千千 & ツ州川 & テ 天 & 卜 \\
\hline なな奈 & に仁仁 & ぬ女奴 & ね被祢 & のカろ & 十 奈 & 二 仁 & 又 奴 & 永 袮 & ノ \\
\hline は泬波 & ひ比 & ふ不不 & へろ部 & ほ保保 & 八八 & 七 比 & フ 不 & へ 部 & ホ 保 \\
\hline まま末 & み灵美 & む老武 & め女女 & も毛毛 & マ末 & ミ三 & 么 牟 & メ 女 & 乇毛 \\
\hline や也也 & 吸引以 & ゆ由 由 & 记江江 & よよ与與 & ヤ也 & 1 以 & 工 由 & 1 衣 & $\exists$ \\
\hline ら方良 & り利利 & る万留 & れ礼 & 万万吕 & ラ 良 & リ利 & ル 流 & $V$ 礼 & 口 \\
\hline わ和 & みみ爲 & & 点急恵 & をを遠 & ワ 和 & 年井 & 千 宇 & 工 恵 & 7 \\
\hline & & んえ无 & & & & & ン 尔 & & \\
\hline
\end{tabular}

Fig. 1. Kana Development Chart [9].
Among the many types of games, typing games are the type of games that are very suitable for language learning. Where typing games can improve one's ability in typing can also train one's ability to spell and train the sentence structure (grammar) of a language of course in a more fun way [14]. Because of the benefits of typing games for language learning, now many typing games are available to learn various types of languages such as word games for folk play learning [16] and the kana no shensi for learning Japanese hiragana and katakana letters [17].

\section{Motivation Through Game}

Video games give rise to many types of motivation, starting from the desire to compete, fantasy, excitement, relaxation and others. This is not necessarily obtainable in traditional learning methods [18]. Because video games can evoke strong emotional feelings and provide a sense of satisfaction in the learning process [19]. If someone who is learning feels a pleasant experience while learning, then this will make that person motivated to continue learning [6].

Game-Based Learning Approach is highly recommended as a learning method because of its potential to practice decision-making skills and is suitable for use in various study areas [20], [21].

One of the studies conducted by Monter $\mathrm{M}$ et al. where he tested the process of learning English for students who used Arabic as their daily language. In his research he found that the use of video game in English class made students happier and some of the students continued the games in their spare time at home. Even further, in this research he suggested making the use of game applications as part of the curriculum and using the application. used throughout the semester to see the full potential of the use of game applications in the learning process [22].

\section{RESEARCH METHODS}

The research method used is Game-Based Learning. According to Linek et al. Game-Based Learning is edutainment that utilizes the motivational and immersive aspects of video games in an educational context. The available methodology for Game-Based Learning is in the form of Enhanced Learning Experience and Knowledge Transfer (ELEKTRA) [7]. ELEKTRA has eight phases to ensure a clear workflow, which is shown in Fig. 2.

1) Phase 1: Identify instructional goals: At this stage, a search and analysis of the problem are carried out, and then the solution is sought by designing the targets and objectives of the learning video game. In the first phase, the target audience and how the game is implemented is determined as the next design determination. The target audience is then determined in phase 3. Requirement Analysis from Black Box Testing is also held in this phase.

2) Phase 2: Instructional analysis: In this phase, the team collects data that provides a solution to achieve the goals that have been determined from Phase 1. In the case of learning video games, this can be done by researching learning 
materials, then, how to implement these learning materials as games.

3) Phase 3: Analyze learners and context of learning: In this phase, the focus is given to the analysis of the players themselves. The target audience was analyzed through a questionnaire survey. The results of the survey and questionnaire are used in this phase as a determination of entry skills for various levels in this game. For players, the entry skills for this game are as follows in brief:

- Hiragana: Understand how to write Hiragana

- Katakana: Understand how to write Katakana

- N5 Kanji: Understand how to write Hiragana and learn Kanji from outside sources.

Here also uses a questionnaire to determine the wishes of the players, and the results of the questionnaire are used as material for discussion in this phase.

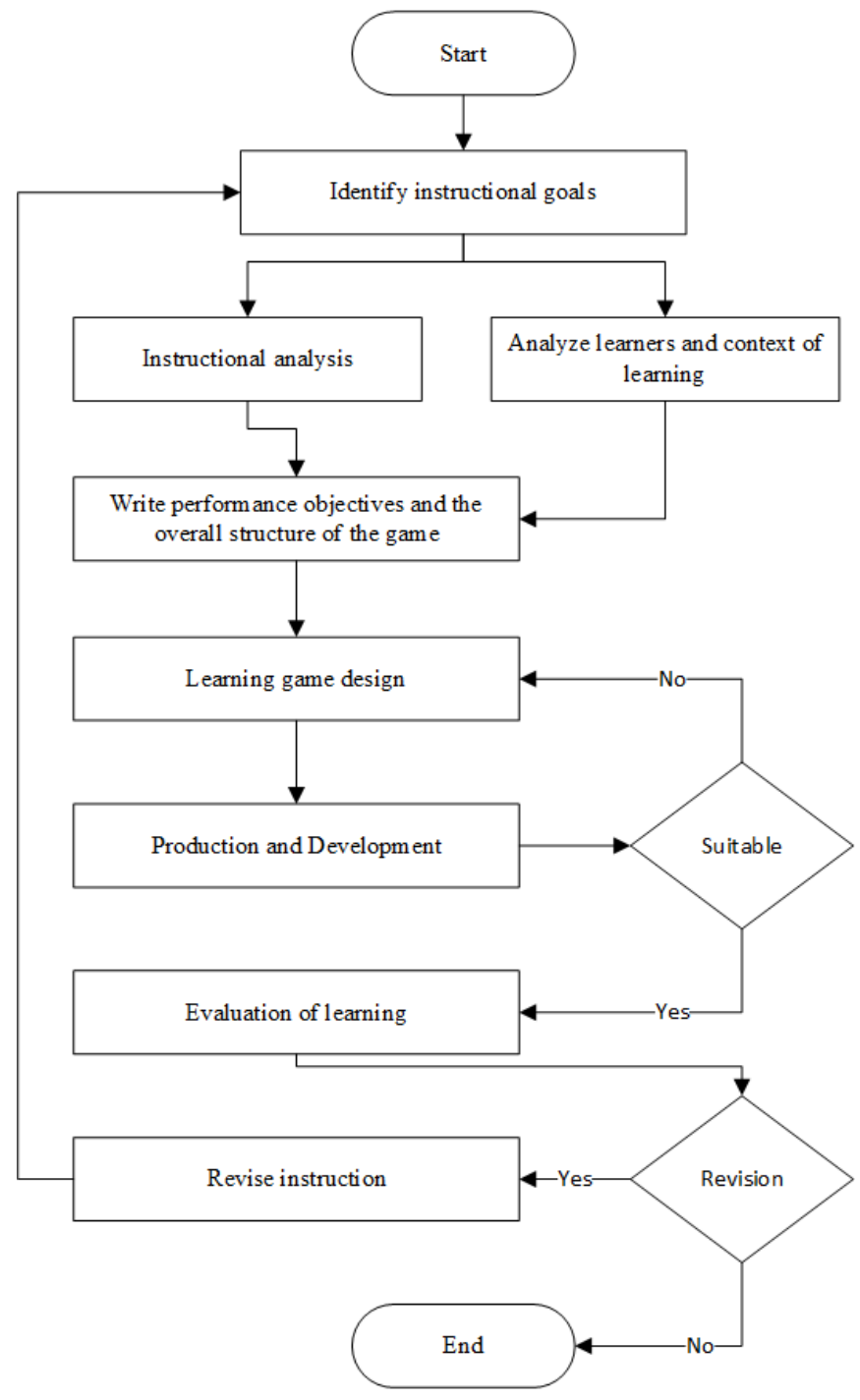

Fig. 2. ELEKTRA.
4) Phase 4: Write performance objectives and the overall structure of the game: From the results of Phase 3 and its entry-level, this information is used to determine the desired performance goals for players. After the entry level and performance targets are determined, then the problems and solutions are formulated. The overall structure of the game is formally explained using Storyboarding. Design Specifications are also determined in this phase to provide clear objectives to the programmer.

5) Phase 5: Learning game design: After finishing designing targets based on the results of the previous stages, the design of the game begins with Game Design Document, display design, game performance design, and test design. This stage is also the first stage of the research practicum from the previous stages, and over time, features that are not feasible or cannot be implemented are discarded, or added to create the most appropriate User Experience for the target audience. The way this game works is as follows:

- Players start at the Main Menu and can choose the type of Japanese writing, namely Hiragana, Katakana, and JLPT N5.

- After selecting a level, Letters/words will appear on the screen, then the player is expected to type the spelling before the letters/words fall to the bottom, taking one of the player's three lives.

- The game ends when lives reach empty. Then, the player can choose to restart again or return to the home screen.

6) Phase 6: Production and Development: After the design process has been completed, the programming of this game begins using the $\mathrm{C \#}$ language in Unity. At this stage, everything that has been learned from the previous stage is used to design a game according to the design and especially the targets that have been determined from the first stage.

This phase also includes the testing phase. That is internally and externally. Internal testing or referred to as the alpha version is carried out internally to test every part of the game to look for bugs that can appear while playing, find the root of the problem, and fix the game using Black Box Testing theory.

After the game has been cleaned of as many bugs and features as possible are added and removed through game design changes (phase 5), the game is entered into the External testing section, or known as the beta version, where the game is given to questionnaire participants and managed through a pre-test and post-test. Constraints found from the External testing phase can be managed and updated to a newer beta version.

The process will continue to return to phase 5 every time there is an update until no more changes need to be made. If no changes are needed, the development process continues to phase 7 . 
7) Phase 7: Evaluation of learning: Evaluation of the learning process is carried out by using the results of the posttest of the questionnaire participants as evidence and results of the game design that has been made, and then determining whether the game has achieved the desired target.

8) Phase 8: Revise instruction: The revision of the Evaluation results is used as a guide for features that should be added, changes that need to be made before the game is finally ready to be released and used as determined from Phase 1 .

\section{RESULT AND ANALYSIS}

Fig. 3 to 10 are the results of Japanese language video game-based learning called "Typing Japan". This video game will run on a PC/Desktop with a minimum operating system of Windows 7 SP1+, macOS10.12+ or Ubuntu 16.04+, and musthave graphics capabilities to run DirectX 10.

This video game is divided into two main menus in this game, which are as follows:

1) Writing Style, wherein this menu the user will determine the type of word to be played. In this case, there are 3 types of word choices, namely: Hiragana, katakana, and N5 Kanji. and in the process of selecting the type of word to be played, the user will also be given the option to choose the level they want to learn, for example on the Hiragana menu there will be options for Syllables I, Syllables II, Dakuten, Yoon, All Syllables, and Full Set.

2) The game itself: The way to play this game application is by typing the spelling of the letter from the letters that fall before touching the bottom of the screen. When the player starts writing from the letter, the letter changes color to red. When the player finishes writing the letter, the letter turns green and disappears. In this game, the player is initially given three lives. When the letter hits the bottom of the screen, the player's life will be reduced by one. The game ends when the player has run out of lives. Click the back button to return to the Writing Style Mode menu.

This game application was evaluated to 30 respondents who wanted to learn Japanese with several methods:

1) Obtaining feedback from the target user through a questionnaire to determine how effectively the game "Typing Japan" helps increase insight by collecting comparative data from the pre-play and post-play Questionnaire. Collect the requirements needed by the user to be implemented into game applications.

2) The Alpha Testing process uses the Black Box Testing methodology to check if the video game works well.

3) Getting feedback from Open Beta players will help evaluate the game from the player's perspective to maximize Game Experience (GX) when the game is released and published to the public.

At the testing stage, pretest and posttest were carried out to determine the increase in knowledge after using the application, so that an increase in the ability of 27 of 30 users is obtained.

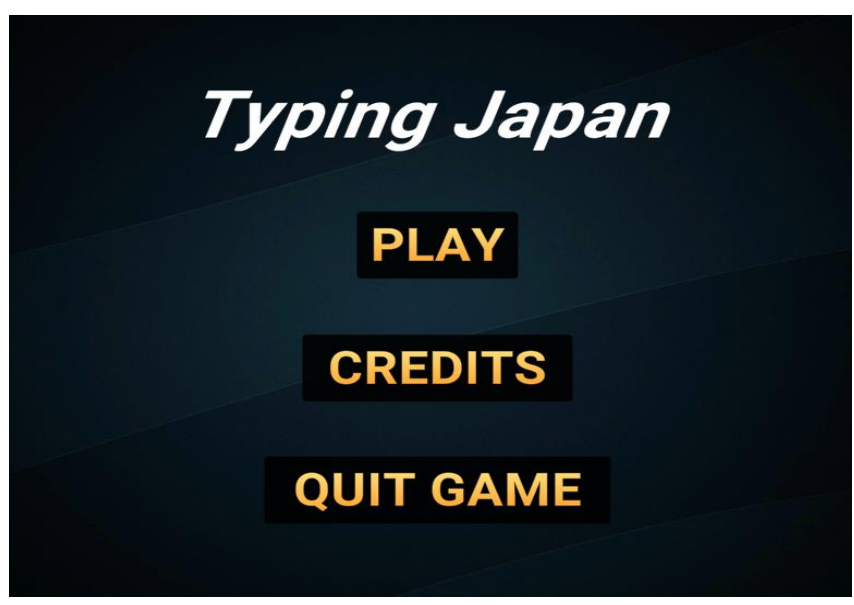

Fig. 3. Main Menu.

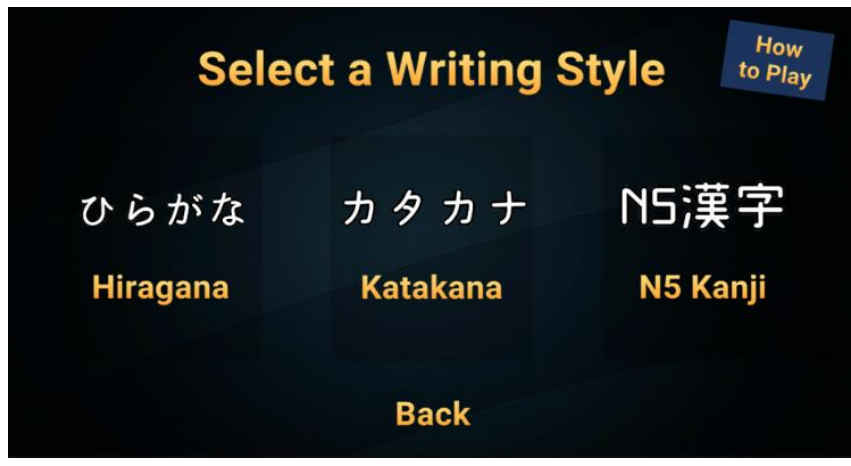

Fig. 4. Writing Style Mode.

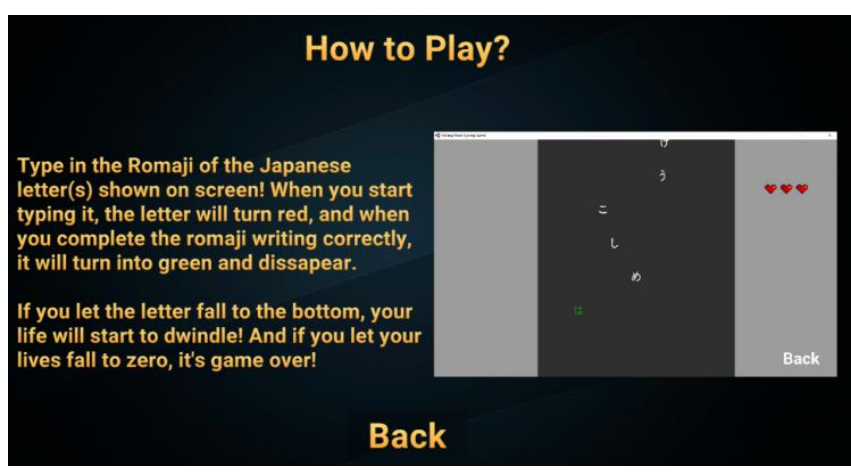

Fig. 5. How to Play.

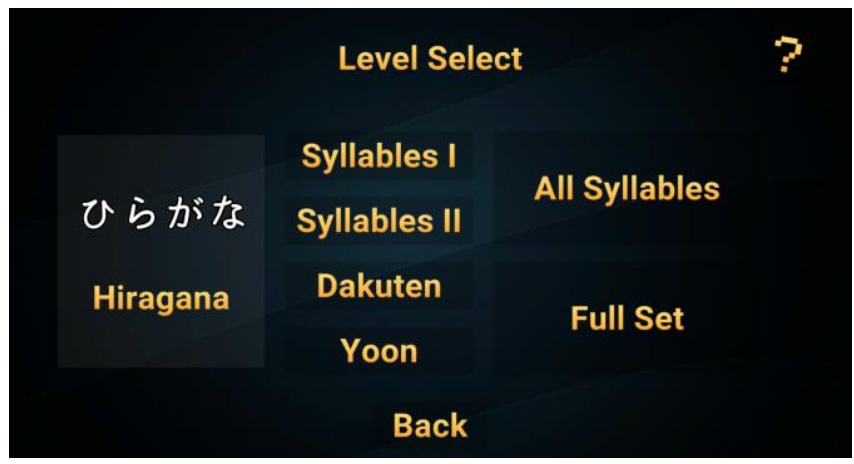

Fig. 6. Hiragana Menu. 


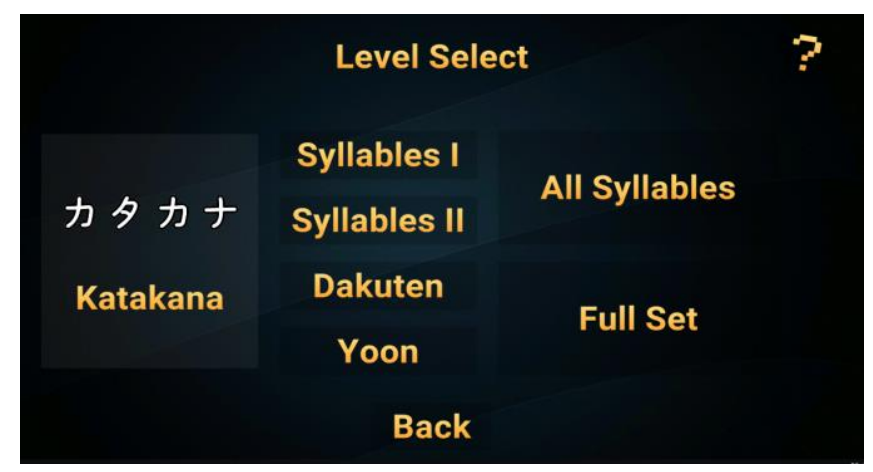

Fig. 7. Katakana Menu.

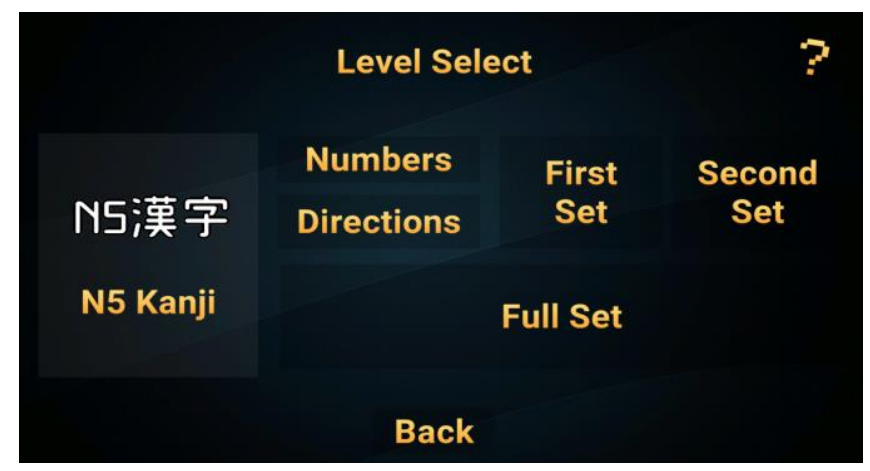

Fig. 8. N5 Kanji Menu.

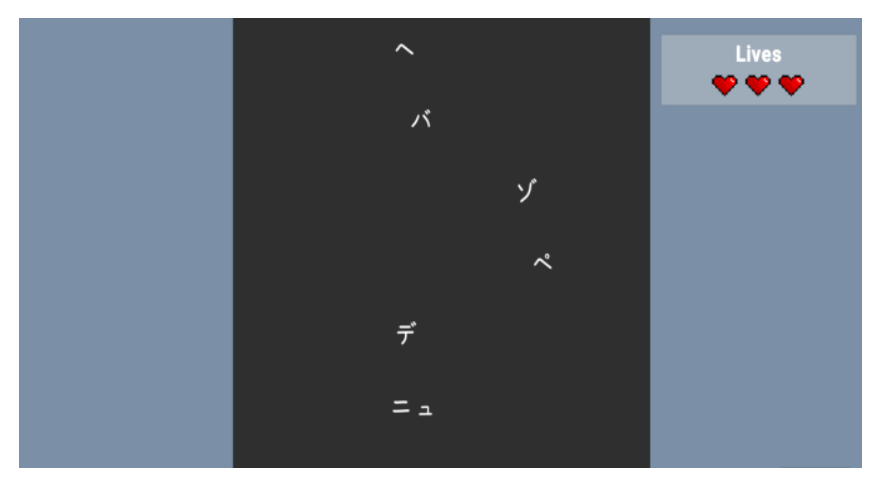

Fig. 9. Gameplay.

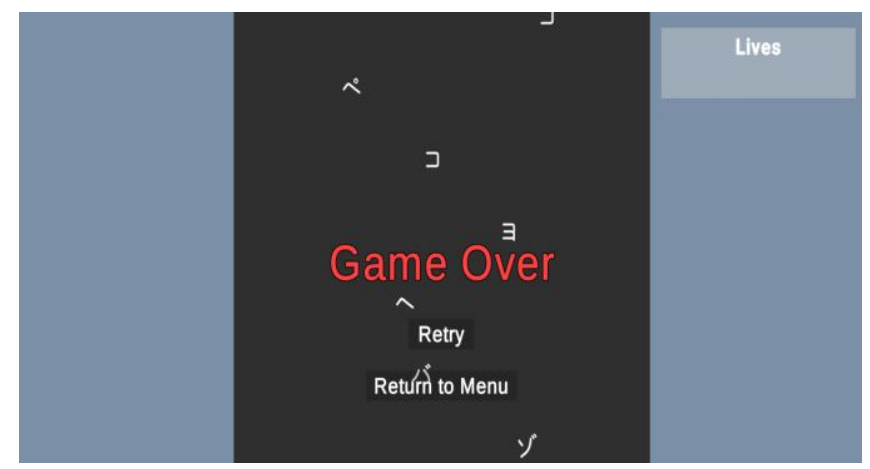

Fig. 10. Game Over.

Besides that, the use of video games can increase a person's interest in continuing to learn Japanese. 23 out of 30 users stated that they are very happy and interested in continuing to learn. While 7 other users stated that they were quite happy with the learning process through video games.
In addition to conducting user satisfaction questionnaires, Alpha Testing was also carried out. The entire Alpha Testing process is carried out internally with the Black Box Testing methodology. Black-box testing is testing done without knowing the source code of the project. Based on the test results, all functions of the application can run well and can be accepted by the user.

In terms of appearance and experience in playing, based on the results of the post-playing questionnaire, it is stated that the game still needs a lot of improvement. This can be in the form of sound effects, music, feedback when writing a letter/word incorrectly, as well as other feedback such as scoring, grading, and sense of progress. All of this requires more experience in database programming. In addition, the UI on the Main Menu and Gameplay has been stated quite clearly and the gameplay can be stated smoothly.

\section{DISCUSSION AND CONCLUSION}

Everyone has different abilities. There are people who can quickly understand something with just one look, while there are people who have to study hard to understand something. In terms of language learning, the intensity of a person to keep practicing foreign language skills will greatly affect a person's learning speed. The more often a person trains his abilities, the more a person's ability to speak a foreign language will increase.

The existence of video games can be a method of training language skills that attract users' interest and support users to practice their language skills on an ongoing basis because the display is much more attractive than a textbook can also be accessed when outside the classroom.

This learning process will be even more interesting if it is supported by good audiovisuals and sound effects. It will be even more interesting if the video games are supported by technology that utilizes the internet such as multiplayer, leaderboard, etc. [23]. These things can speed up the learning process by taking advantage of the competitiveness and resilience of the user.

\section{REFERENCES}

[1] Y. Udjaja, "Gamification Assisted Language Learning for Japanese Language Using Expert Point Cloud Recognizer," Int. J. Comput. Games Technol., vol. 2018, 2018, doi: 10.1155/2018/9085179.

[2] Y. Udjaja, Renaldi, Steven, K. Tanuwijaya, and I. K. Wairooy, "The use of role playing game for Japanese language learning," Procedia Comput. Sci., vol. 157, pp. 298-305, 2019, doi: 10.1016/j.procs.2019.08.170.

[3] N. Haristiani and D. B. Firmansyah, "Android application for enhancing Japanese JLPT N5 kanji ability,” J. Eng. Sci. Technol., vol. 12, no. Special Issue 10, pp. 106-114, 2017.

[4] "Contoh Lowongan Kerja untuk Pemegang Sertifikat JLPT | Tomodachi | Kursus Bahasa Jepang.” https://www.tomodachi-indo.com/lowongankerja/ (accessed Dec. 11, 2021).

[5] "Survei Lembaga Pendidikan Bahasa Jepang di Indonesia tahun 2012 Mayantara School." https://mayantara.sch.id/artikel/survei-lembagapendidikan-bahasa-jepang-di-indonesia-tahun-2012.htm (accessed Dec. 11, 2021).

[6] A. Alamri, "Should Video Games Be Included in the Learning Process?," Int. J. Educ., vol. 8, no. 1, p. 23, 2016, doi: 10.5296/ije.v8i1.8388.

[7] S. B. Linek, D. Schwarz, M. Bopp, and D. Albert, "Game-based learning:Conceptual methodology for creating educational games," WEBIST 2009 - Proc. 5th Int. Conf. Web Inf. Syst. Technol., no. 
January, pp. 135-142, 2009.

[8] H. Rose, "Unique challenges of learning to write in the Japanese writing system,” L2 Writ. Beyond English, no. May, pp. 78-94, 2019, doi: 10.21832/9781788923132-008.

[9] K. Nute, "Toward a Test of Cultural Misappropriation," no. April, 2020, doi: 10.18848/2327-0055/CGP/v17i02.

[10] NHK, "Hiragana | Cara Mudah Berbahasa Jepang | NHK WORLDJAPAN." https://www.nhk.or.jp/lesson/id/letters/hiragana.html (accessed Dec. 11, 2021).

[11] Y. Okuyama, "CALL Vocabulary Learning in Japanese: Does Romaji Help Beginners Learn More Words?," CALICO J., vol. 24, no. 2, pp. 355-379, 2013, doi: 10.1558/cj.v24i2.355-379.

[12] A. S. Dylman and M. Kikutani, "The role of semantic processing in reading Japanese orthographies: an investigation using a script-switch paradigm," Read. Writ., vol. 31, no. 3, pp. 503-531, 2018, doi: 10.1007/s11145-017-9796-3.

[13] T. Ogino, K. Hanafusa, T. Morooka, A. Takeuchi, M. Oka, and Y. Ohtsuka, "Predicting the reading skill of Japanese children," Brain Dev., vol. 39, no. 2, pp. 112-121, 2017, doi: 10.1016/j.braindev.2016.08.006.

[14] T. L. Wang, T. K. Chen, and Y. F. Tseng, "An leaner-centred, gamebased, learning framework for typing games in english course," 3CA 2010 - 2010 Int. Symp. Comput. Commun. Control Autom., vol. 1, no. June 2010, pp. 93-95, 2010, doi: 10.1109/3CA.2010.5533723.

[15] B. Klimova and J. Kacet, "Efficacy of computer games on language learning," Turkish Online J. Educ. Technol., vol. 16, no. 4, pp. 19-26, 2017.

[16] Y. Bae, H. Choe, T. Lee, and T. Kim, "Folk Play Learning System
Based on Word Games," pp. 0-1, 2004.

[17] K. Stubbs, "Kana no Senshi (Kana Warrior): A new interface for learning Japanese characters," Conf. Hum. Factors Comput. Syst. Proc., no. January 2003, pp. 894-895, 2003, doi: 10.1145/765891.766054.

[18] Y. Udjaja, V. S. Guizot, \& N. Chandra, "Gamification for elementary mathematics learning in Indonesia." International Journal of Electrical and Computer Engineering (IJECE), 8(6), 2018.

[19] Y. Udjaja, Sasmoko, A. S. Rumapea, F. A. Putra, \& T. Rahmansyah, "Architecture of High-Order Thinking Skills Game to Improve Ability." In 2019 IEEE International Conference on Engineering, Technology and Education (TALE) (pp. 1-4). IEEE, 2019, December.

[20] P. Kinnerk, S. Harvey, C. MacDonncha, and M. Lyons, "A Review of the Game-Based Approaches to Coaching Literature in Competitive Team Sport Settings," Quest, vol. 70, no. 4, pp. 401-418, 2018, doi: 10.1080/00336297.2018.1439390.

[21] F. S. Breien and B. Wasson, "Narrative categorization in digital gamebased learning: Engagement, motivation \& learning," Br. J. Educ. Technol., vol. 52, pp. 2021-91, 2020, doi: 10.1111/bjet.13004.

[22] M. M. Elaish, N. A. Ghani, L. Shuib, and A. Al-Haiqi, "Development of a Mobile Game Application to Boost Students' Motivation in Learning English Vocabulary,' IEEE Access, vol. 7, pp. 13326-13337, 2019, doi: 10.1109/ACCESS.2019.2891504.

[23] Byun, JaeHwan \& Loh, Christian. (2015). Audial engagement: Effects of game sound on learner engagement in digital game-based learning environments. Computers in Human Behavior. 10.1016/j.chb.2014.12.052. 